\title{
IMPLEMENTASI NILAI-NILAI DEMOKRATIS DAN HUMANISTIK DALAM PENDIDIKAN ISLAM
}

\section{Oleh : ZAINUDDIN ${ }^{1}$}

\begin{abstract}
Abstrak: Dalam pendidikan demokrasi dan humanistik, guru tidak hanya dituntut harus profesional yang memiliki berbagai kompetensi, tetapi juga harus mampu membantu para murid untuk mengenal diri mereka sebagai sosok manusia yang unik, dan juga harus mampu membantu mereka dalam mengembangkan potensi yang mereka miliki secara optimal. Dalam hal ini, guru tidak hanya mengajarkan berbagai materi pelajaran berbagai agar murid menguasai mata pelajaran tersebut dan kemudian memperoleh nilai yang tinggi ataupun lulus dalam menempuh ujian, namun juga masih banyak hal penting yang yang harus dilakukan guru, yaitu membantu murid untuk menemukan nilai-nilai yang terandung dalam setiap mata pelajaran yang akan diimplementasikan mereka dalam kehidupan sehari-hari. Guru juga harus membantu murid untuk menemukan dan selanjutnya memiliki kepribadian yang baik, karakter yang baik, dan memiliki perilaku yang baik pula. Ini semua adalah tugas utama seorang guru dalam pendidikan dan juga merupakan tujuan dari pendidikan Islami dalam pendidikan demokrasi dan pendidikan humanistik.
\end{abstract}

\section{Kata kunci: demokrasi, humanistik, pendidikan islami}

\section{Pendahuluan}

Penyelenggaraan pendidikan yang dilaksanakan di berbagai lembaga pendidikan, seperti di lembaga pendidikan formal, non formal, dan in formal pada dasarnya dapat dipandang sebagai salah satu bentuk perwujudan kebudayaan manusia haruslah bersifat dinamis dan selalu berkembang, sebab perkembangan dalam dunia pendidikan adalah hal yang seharusnya terjadi sejalan dengan perubahan budaya kehidupan umat manusia. Perubahan dimaksud dalam arti perbaikan pendidikan yang mencakup pada semua tingkat dan aspek, baik pada sisi konsep, kurikulum, kualitas sumber daya manusia, metode pembelajaran, lembaga-lembaga, organisasi, sistem evaluasi, serta penerapan reward dan punishment (Haryanto Al Fandi, 2011). Kesemuanya ini penting untuk terus diupayakan agar pendidikan dapat

\footnotetext{
${ }^{1}$ Zainuddin : Dosen Jurusan Pendidikan Dasar FKIP Untan
} 
relevan dengan perubahan sosial budaya masyarakat yang terus berkembang dan sesuai dengan karakteristik global yang mendambakan adanya transparansi atau keterbukaan, perlakuan yang sama dan adil bagi setiap manusia sebagai wujud dari perlakuan yang demokratis serta menjunjung tinggi hak-hak asasi manusia sebagai wujud dari perlakuan yang humanistik.

Sehubungan dengan itu penting kiranya memasukkan nilai-nilai positif demokrasi dan humanisme dalam sistem pendidikan dengan harapan proses pendidikan dan pembelajaran berlangsung lebih demokratis dan humanis sehingga akan melahirkan generasi bangsa yang sadar akan eksistensi dirinya sebagai makhluk religius sekaligus makhluk sosial. Menurut Gerald Corey (dalam Koeswara, 1988) dalam Humanistik manusia memiliki kesanggupan yang unik dan nyata yang memungkinkan manusia mampu berpikir dan memutuskan. Selanjutnya Hall \& Linzey (1985) mengatakan the humanistic science he proposes would not substitute for mechanistic science but would serve to complement it, dealing with questions of value, individuality, consciousness, purpose, ethics, and the higher reaches of human nature.

\section{Kurukulum Demokratis dan Humanistik}

Kurikulum merupakan segala kegiatan yang dirancangnoleh lembaga pendidikan dan yang sisajikan untuk mencapai tujuan pendidikan. Menurut pengertian ini, segala pengalaman yang dialami peserta didik adalah kurikulum, sebab kurikulum tidak terbatas hanya pada pengalaman, ruang, dan tempat tertentu, tetapi pada setiap pelajaran yang berlangsung. Hal ini sejalan dengan pendapat harold B. Alberty dan Elsie J. Alberty (dalam Ahmad Tafsir, 1994) yang mengatakan bahwa kurilukum adalah semua aktivitas atau kegiatan yang dilakukan oleh peserta didik sesuau dengan peraturan-peraturan.

Dalam konsepsi pendidikan Islam, kurikulum dikenal dengan istilah manhaj yang berarti sebuah jalan terang yang dilalui pendidik atau guru dengan orang-orang yang dididik untuk mengembangkan pengetahuan, keterampilan, dan sikap mereka (Oemar Muhammad al Taomy al Syaibani, 1979).

Dalam konteks pendidikan nasional, kurikulum didefinisikan sebagai rencana tertulis tentang kemampuan yang harus dimiliki berdasarkan standar nasional, materi yang perlu dipelajari dan pengalaman belajar yang harus dijalani untuk mencapai kemampuan tersebut. Juga adanya evaluasi yang perlu dilakukan untuk menentukan tingkat pencapaian kemampuan peserta didi dan seperangkat peraturan yang berkenaan dengan pengalaman belajar peserta didik daam mengembangkan potensi dirinya pada satuan pendidikan 
tertentu. Dengan lebih spesifik, rumusan ini mengandung pokok-pokok pemikiran sebagai berikut :

1. Kurikulum merupakan suatu rencana.

2. Kurikulum merupakan pengaturan yang sistematis dan terstruktur.

3. Kurikulum memuat isi dan bahan pelajaran bidang pengajaran tertentu.

4. Kurikulum mengandung cara, metode, dan strategi pengajaran.

5. Kurikulum merupakan pedoman kegiatan belajar mengajar

6. Kurikulum dimaksudkan untuk mencapai tujuan pendidikan.

7. Kurikulum merupakan suatu alat pendidikan.

Dengan demikian dapat pula dikatakan bahwa kurikulum merupakan suatu patokan rencana-rencana dalam penyelenggaraan yang memiliki tujuan dan cita-cita tertentu yang berdasarkan pada pengalaman-pengalaman pembelajaran sebelumnya, bersifat fleksibl dan didesain oleh sekolah agar peserta didik memiliki representasi fungsi langsung di masyarakat.

Dalam setiap satuan pendidikan, kurikulum merupakan komponen yang sangat penting dan strategis karena di dalamnya berisikan tentang rumusan tujuan yang harus dicapai, materi pelajaran yang harus dipelajari, cara atau metode untuk mempelajari, serta bagaimana cara untuk mengetahui pencapaiannya atau evaluasi (Purwoto, 2003).

Kurikulum merupakan bagian yang tidak bisa dipisahkan dengan komponen pendidikan lainnya. Tanpa kurikulum, suatu sistem pendidikan tidak dapat dikatakan sebagai sistem pendidikan yang sempurna, sebab kurikulum dalam sistem pendidikan merupakan ruh atau spirit yang menjadi gerak dinamik suatu sistem pendidikan. Selain itu kurikulum juga sebagai sebuah idea vital yang menjadi landasan bagi terselenggaranya pendidikan yang baik, sekaligus juga sebagai tolok ukur bagi kualitas penyelenggaraan pendidikan dan sebagai kerangka acuan dalam memberikan arah terhadap pencapaian tujuan pendidikan dari tingkat nasional sampai pada tingkat interaksi di kelas. Berhasil atau tidaknya suatu pendidikan, mampu tidaknya seorang anak didik dan pendidik dalam menyerap dan memberikan pengajaran, dan sukses tidaknya suatu tujuan sangat bergantung pada kurikulum yang diterapkan dalam suatu pendidikan tersebut. Bila kurikulum didesain dengan sistematis dan komprehensif serta integral dengan segala kebutuhan pengembangan dan pembelajaran anak didik untuk mempersiapkan diri menghadapi kehidpannya, tentu hasil pendidikan pun akan mempu mewujudkan harapan tersebut. Tetapi jika tidak, kegagalan demi kegagalan akan terus-menerus membayangi dunia pendidikan.

Dalam konfigurasi sistem pendidikan di Indonesia, seiring dengan perjalan waktu telah mengalami perkembangan yang cukup pesat dalam hal kurikulum. Hingga saat ini dunia pendidikan di Indonesia sudah berkali-kali 
mengalami perubahan kurikulum, setidaknya sudah tujuh kali perubahan kurikulum yang tercatat dalam sejarah, yakni Kurikulum 1962, 1968, 1975, 1984, 1994, dan 2004 yang berbasis kompetensi (KBK), kemudian diperbaharui dengan Kurikulum 2006 (KTSP) yang saat ini sedang diterapkan. Perubahan kurikulum sejak kurikulum yang pertama (Kurikulum 1962) hingga Kurikulum 2006 (KTSP), ternyata belum juga membawa dampak positif terhadap perkembangan mutu di dunia pendidikan sehingga sampai saat inipun mutu pendidikan kita masih rendah. Atas dasar itu diperlukan adanya terobosan baru dalam pengembangan kurikulum, yaitu sebuah kurikulum pendidikan yang menyediakan ruang bagi ekslporasi masalah kemanusiaan dan kurikulum yang dapat membantu peserta didik untuk mengembangkan potensinya secara optimal. Selain itu kurikulum ini harus kurikulum yang tidak hanya menekankan pada pengembangan aspek kognitif saja, tetapi juga banyak menekankan pada aspek afektif, dan aspek psikomotorik secara integral dan komprehensif.

Perubahan kurikulum yang harus dilakukan ini didasarkan pada pertimbangan bahwa peserta didik adalah subjekyang menjadi pusat pendidikan yang mempunyai potensi, kemampuan, dan kekuatan untuk berkembang. Di samping itu, hahekat dan kebutuhan anak didik serta hahekat dan kebutuhan pokok di masyarakat juga menjadi dasar perubahan kurikulum dengan haapan ilmu yang dipelajari peserta didik tidak menjadi menara gading di mana peserta didik berinteraksi. Hal ini sesuai dengan pendapat John Dewey (dalam M. Yunus Firdaus, 2004) yang mengatakan bahwa dalam mengebangkan sebuah kurikulum di segala tingkatan hasurlah memperhatikan tiga butir berikut:

1. Hahekat dan kebutuhan siswa-siswa.

2. Hahekat dan keb utuhan masyarakat di mana para peserta didik meupakan bagian dari masyarakat tersebut.

3. Masalah pokok yang digumuli peserta didik utuk mengembangkan diri sebagai pribadi yang matang dan mampu menjalin hubungan yang baik dengan masyarakat.

Berdasarkan pendapat ini tampak urgensinya pengembangan kurikulum pendidikan ke arah kurikulum yang lebih demokratis dan humanistik. Suatu desain kurikulum yang menyediakan pengalaman berharga dalam memperlancar perkembanganpribai dinamis yang diarahkan pada pertumbuhan, integritas, otonomi kepribadian, serta sikap yang sehat atau positif terhadap diri sendiri, orang lain, maupun saat belajar. Semua ini merupakan bagian dari cita-cita perkembangan manusia yang teraktualisasi dalam dirinya (self actualizing person). Sebab apabila peserta didik telah mampu mengaktualisasikan dirinya, ia akan dapat mencapai keseimbangan 
atau harmoni perkembangan seluruh aspek pribadinya, baik aspek kognitif, afektif, estetika, dan moral maupun psikomotorik. Menurut pandangan humanistik manusia memiliki kesanggupan untuk menyadari dirinya sendiri, suatu kesanggupan yang unik dan nyata yang memungkinkan manusia mampu berpikir dan memutuskan yang terbaik bagi dirinya. Semakin kuat kesadaran diri itu pada seseorang, maka akan semakin besar pula kebebasan yang ada pada orang itu (Gerald corey, dalam Koeswara : 1988).

Perkembangan kurikulum ke arah kurikulum yang demokratis dan humanistik ini, menuntut hubungan emosional yang baik antara dengan peserta didik. Setiap kegiatan yang dilakukan oleh pendidik adalah kegiatan yang baik dan bermanfaat bagi peserta didik, yakni kegiatan yang memberikan pengalaman yang baik akan membantu peserta didik dalam memperluas kesadaran akan dirinya dan orang lain, serta dapat mengambangkan porensi-porensi yang dimilikinya (M. Yunus Firdaus, 2004). Dalam hal ini pendidik selain harus mampu menciptakan hubungan yang hangat dan akrab dengan peserta didiknya, ia juga harus menjadio sumber inspirasi bagi terciptanya keharmonisan tersebut. Kurikulum yang demokratis dan humanistik juga harus mampu menjadi solusi bagi berbagai problem yang sedang dihadapi oleh dunia pendidikan saat ini, terutama pada aspek moralitas peserta didik dan bahkan pendidik yang pada dekade terakhir ini mengalami degradasi moral yang cukup memperihatinkan. Ini artinya kurikulum harus menyajikan materi yang memungkinkan bagi tumbuhnya sikap kritis, akhlak terpuji, kepedulian sosial yang tinggi, kesadaran akan nilai-nilai kemanusiaan, kesadaran akan adanya perbedaan antar individu, dan seterusnya. Hal lain yang mesti diperhatikan adalah kurikulum harus bersifat komprehensif dan mampu memberikan pengalaman yang menyeluruh pada pesera didik, bukan pengalaman yang parsial.

Dalam hal evaluasi, konsep kurikulum yang demokratis dan humanistik berbeda dengan kurikulum biasa. Model kurikulum ini lebih mengutamakan proses daripada hasil. Jika kurikulum yang biasa digunakan terutama subjek akademis mempunyai kriteria pencapaian tertentu, dalam kurikulum yang demokratis dan humanistik tidak ada kriteria tertentu, sebab sasaran dari kurikulum ini adalah perkembangan anak supaya menjadi manusia yang lebih terbuka (open minded) dan mandiri di dalam menciptakan kreativitas dan aktivitas. Kurikulum ini berfungsi menyediakan pengalaman pengetahuan berharga untuk membantu memperlancar perkembangan pribadi peserta didik yang dinamis saat belajar maupun di lingkungan masyarakat sesuai prinsip integritas, yaitu prinsip integrasi antara perilaku kognitif, afektif, dan psikomotorik yang diarahkan pada 
pertumbuhan, integritas, otonomi kepribadian serta sikap yang sehat terhadap diri sendiri dan orang lain menuju terciptanya manusia ideal (insan kamil).

Dari penjelasan di atas dapat dikatakan bahwa kurikulum yang demokratis dan humanistik adalah kurikulum pendidikan yang setidaknya memiliki karakteristik sebagai berikut :

1. Tujuan dari pendidikan dalam kurikulum ini adalah proses perkembangan pribadi yang dinamis.

2. Pendidikan dan pembajaran menuntut adanya hubungan emosional yang baik antara pihak pengajar dan peserta didik.

3. Dalam prinsipnya menekankan pada integrasi intelektual, emosional, spiritual, dan tindakan nyata dalam aspek kognitif, afektif, dan psikomotor.

4. Menyediakan pengalaman dan pengetahuan berharga untuk membantu memperlancar perkembangan pribadi peserta didik sesuai fitrahnya secara optimal.

5. Dapat membantu peserta didik menghadapi masalah kehidupan sehari-hari dengan arif dan bijaksana.

6. Menyajikan materi yang memungkinkan bagi tumbuhnya sikap kritis bagi peserta didik.

7. Dalam hal evaluasi lebih mengutamakan proses daripada hasil dan tidak ada kriteria tertentu.

\section{Pendidik Demokratis dan Humanistik}

Dari sekian banyak komponen pendidikan, pendidik merupakan faktor yang sangat penting dan strategis dalam usaha meningkatkan mutu pendidikan di setiap satuan pendidikan. Istilah pendidik jika dilihat dari segi etimologi berarti orang yang mendidik atau orang yang memberi bimbingan. Sedangkan secara terminologi, pendidik memiliki arti yang beragam. Menurut Ahmad D. Miramba (1987) pendidik adalah orang yang memikul tanggung jawab untuk mendidik. Sementara Amir Dien Indrakusuma mendefinisikan pendidik sebagai pihak yang mendidik, pihak yang memberikan anjuran-anjuran, pihak yang berbagi pengetahuan dan kecakapan, serta pihak-pihak yang turut menghumaniskan anak. Selanjutnya Samsul Nizar (2002) mengatakan bahwa pendidik adalah orang yang bertanggung jawab atas perkembangan peserta didik dengan upaya mengembangkan seluruh potensi peserta didik, baik potensi kognitif (cipta), kognitif (rasa), maupun psikomotorik (karsa). Ini artinya seorang pendidik atau guru tidak hanya memberi materi di depan kelas, tetapi ia juga harus aktif dan berjiwa kreatif dalam mengarahkan perkembangan peserta didiknya secara optimal. 


\section{Istilah Pendidik Dalam Literatur Islam}

Dalam literatur Islam, pendidik sering disebut istilah ustadz, mu'allim, mursyid, dan mu'addib. Istilah-istilah tersebut memiliki penggunaan sesuai dengan peristilahan pendidikan dalam konteks pendidikan Islam. Berdasarkan istilah-istilah tersebut, Abdul Mujib (dalam Haryanto AlFandi, 2011) mengemukakan beberapa karakteristik pendidik dalam pendidikan Islam yang dituangkannya dalam bentuk tabel sebagai berikut.

\begin{tabular}{|l|l|l|}
\hline No & Pendidik & \multicolumn{1}{c|}{ Karakteristik } \\
\hline 1. & Ustadz & $\begin{array}{l}\text { Orang yang berkomitmen dengan profesionalitas, yang melekat } \\
\text { pada dirinya sikap dedikatif, komitmen terhadap mutu proses dan } \\
\text { hasil kerja, serta sikap continuous improvement. }\end{array}$ \\
\hline 2. & Mu'allim & $\begin{array}{l}\text { Orang yang menguasai ilmu dan mampu mengembangkannya } \\
\text { serta menjelaskan fungsinya dam kehidupan, menjelaskan } \\
\text { dimensi teoritis dan praktisnya, sekaligus melakukan transfer } \\
\text { ilmu pengetahuan, internalisasi, serta implementasi. }\end{array}$ \\
\hline 3. & Murabbi & $\begin{array}{l}\text { Orang yang mendidik dan menyiapkan peserta didik agar mampu } \\
\text { berkreasi serta mampu mengatur dan memelihara hasil kreasinya } \\
\text { untuk tidak menimbulkan malapetaka bagi dirinya, masyarakat, } \\
\text { dan alam sekitarnya. }\end{array}$ \\
\hline 4. & Mursyid & $\begin{array}{l}\text { Orang yang mampu menjadi model atau sentral idedntifikasi diri } \\
\text { atau menjadi anutan, teladan, dan konsultan bagi peserta } \\
\text { didiknya. }\end{array}$ \\
\hline 5. & Mudarris & $\begin{array}{l}\text { Orang yang memiliki kepekaan intelektual dan informasi serta } \\
\text { memperbarui pengetahuan dan keahliannya secara berkelanjutan, } \\
\text { dan berusaha mencerdaskan peserta didiknya, memberantas } \\
\text { kebodohan mereka, serta melatih keterampilan sesuai dengan } \\
\text { bakat, minat, dan kemampuannya. }\end{array}$ \\
\hline 6. & Mu'addib & $\begin{array}{l}\text { Orang yang mampu menyiapkan peserta didik untuk bertanggung } \\
\text { jawab dalam membangun peradaban yang berkualitas di masa } \\
\text { depan. }\end{array}$ \\
\hline 7. & Muhazzib & $\begin{array}{l}\text { Orang yang membersihkan, memperbaiki perilaku dan hati } \\
\text { nurani dengan sesegera mungkin karena adanya suatu } \\
\text { penyimpangan atau kekhawatiran akan adanya penyimpangan } \\
\text { sehingga tahzib itu dapat mewujudkan insan muslim yang berhati } \\
\text { nurani bersih, berperilaku yang baik sesuai dengan ajaran Allah } \\
\text { SwT. }\end{array}$ \\
\hline
\end{tabular}

Berdasarkan tabel di atas, tampak bahwa tugas-tugas pendidik sangat amat berat. Tugas-tugas itu dalam implementasinya tidak saja melibatkan 
kemampuan kognitif, tetapi juga kemampuan afektif dan kemampuan psikomotorik (Abdul Mujib, 2006).

Pendidik merupakan faktor yang sangat penting dalam usaha meningkatkan mutu pendidikan di setiap satuan pendidikan. Bermutu dan tidaknya pendidikan di suatu sekolah sangat ditentukan oleh kemampuan yang dimiliki seorang pendidik dalam menjalankan tugasnya. Sebab pendidik berada dalam posisi terdepan dalam pendidikan seperti yang ditegaskan oleh Zaenal Aqib (2002) bahwa pendidik adalah faktor penentu bagi keberhasilan pendidikan di sekolah karena guru merupakan sentral serta sumber kegiatan belajar mengajar, sekaligus sebagai komponen yang paling berpengaruh dalam peningkatan mutu pendidikan di sekolah.

Dalam proses pendidikan guru memegang tugas ganda, yaitu sebagai pengajar dan pendidik. Menurut Djamarah (2002), baik mengajar maupun mendidik merupakan tugas dan tanggung jawab guru sebagai tenaga profesional. Sebagai pengajar, guru bertugas menuangkan sejumlah bahan pelajaran ke dalam otak anak didiknya, sedangkan sebagai pendidik guru bertugas membimbing, dan membina anak didik agar menjadi manusia susila yang cakap, aktif, kreatif, dan mandiri. Tugas berat dari seorang pendidik ini pada dasarnya hanya dapat dilaksanakan oleh guru yang memiliki kompetensi profesional yang tinggi. Guru yang profesional tidak hanya menguasai bidang ilmu, bahan ajar, menguasai metode yang tepat, mampu memotivasi peserta didik serta memiliki keterampilan yang tinggi dan wawasan yang luas terhadap dunia pendidikan, akan tetapi guru yang profesional juga harus memiliki pemahaman yang mendalam tentang hakekat manusia dan masyarakat. Guru sebagai tenaga profesional juga harus memiliki kompetensi dasar. Kompetensi merupakan satu kesatuan yang utuh yang menggambarkan potensi, pengetahuan, keterampilan, dan sikap yang dinilai yang terkait dengan profesi tertentu berkenaan dengan bagian-bagian yang dapat diaktualisasikan dan diwujudkan dalam bentuk tindakan atau kinerja untuk menjalankan profesi tertentu. Dalam konteks ini, Paul Suparman (2005) mengatakan bahwa kompetensi harus dimiliki seorang guru berkaitan dengan kemampuan guru dalam mengajar, membimbing, dan memberikan teladan hidup kepada murid.

Dalam konteks pendidikan yang demokratis dan humanistik, guru selain harus profesional dan memiliki kompetensi tertentu, ia juga harus mampu membantu anak didiknya untuk mengenali diri mereka sendiri sebagai manusia yang unik, membantu mereka dalam mengembangkan potensi-potensi yang ada secara optimal. Dalam hal ini pendidik tidak hanya menyampaikan materi pelajaran agar peserta didiknya dapat menguasai mata pelajaran kemudian memperoleh nilai yang baik atau lulus ujian. Sebab 
masih ada hal yang lebih penting yang harus menjadi perhatian seorang pendidik, yaitu proses pendewasaan dan membantu peserta didik untuk menemukan sebuah makna dari suatu materi pelajaran yang dapat diterapkan dalam kehidupan sehari-hari, memiliki kepribadian yang baik, santun dan berbudi yang merupakan inti dari tugas guru dalam mendidik. Dengan demikian dapat ditegaskan bahwa pendidik yang demokratis dan humanis adalah pendidik yang mampu membangun suasana belajar yang kundusif untuk belajar mandiri (self directed learning), bermakna, aktif, dinamis, dan menyenangkan (fun).

\section{Peran Guru dalam Pendidikan Demokratis dan Humanistik}

Terkait dengan peran guru dalam proses belajar mengajar, maka seorang guru tidak hanya tampil sebagai pengajar (teacher) seperti perannya yang menonjol selama ini, tetapi ia juga harus bertindak dan berperan sebagai seorang fasilitator, motivator, mediator, counsellor, dan evaluator yang baik.

\section{Fasilitator}

Dalam konteks pendidikan yang demokratis dan humanistik, peran seorang pendidik lebih sebagai fasilitator. Fasilitator baik dalam aspek kognitif, afektif, psikomotorik, maupun konatif. Sebagai fasilitator, pendidik bertugas memberikan motivasi, kesadaran mengenai makna belajar dalam kehidupan peserta didik, dan memberikan kemudahan belajar, bukan hanya menceramahi atau mengajar, apalagi menghajar peserta didik. Sebagai fasilitator, guru mesti bersikap akrab dan penuh tanggung jawab, memperlakukan peserta didiknya sebagai mitra dalam menggali dan mengolah informasi menuju tujuan belajar mengajar yang telah direncanakan.

\section{Mediator}

Guru selain berperan sebagai fasilitator, ia juga berperan sebagai mediator. Sebagai mediator, seorang pendidik dituntut untuk memiliki pengetahuan dan pemahaman yang cukup tentang media pendidikan sebab media merupakan alat komunikasi guna lebih mengefektifkan proses belajar mengajar. Di samping itu, sebagai mediator guru dituntut hadir di tengahtengah siswanya untuk mendorong terjadinya interaksi yang positif dan konstruktif. Dalam kapasitasnya sebagai mediator, tugas utama seorang pendidik adalah membantu peserta didik untuk memformulasikan pertanyaan atau mengkonstruksi representasi visual dari suatu masalah. Selain itu, memandu peserta didik untuk mengembangkan sikap positif terhadap belajar, mengkaitkan informasi baru dengan pengetahuan awal, dan menjelaskan 
bagaimana mengkaitkan gagasan-gagasan, serta pemodelan proses berpikir dengan menunjukkan kepada peserta didik bagaimana berpikir kritis.

\section{Motivator}

Selain berperan sebagai fasilitator dan mediator, seorang pendidik juga berperan sebagai motivator bagi peserta didiknya untuk lebih giat dan bersemangat dalam belajar. Dalam hal ini, tugas guru yang paling utama adalah membangkitkan motivasi peserta didiknya sehingga mereka mau melakukan belajar dengan lebih bersemangat. Motivasi menurut Mulyasa (2007) merupakan faktor yang dapat meningkatkan kualitas pembelajaran karena peserta didik akan belajar dengan sungguh-sungguh apabila memiliki motivasi yang tinggi. Ada beberapa hal yang harus dilakukan pendidik agar motivasi belajar peserta didiknya dapat tumbuh, antara lain (1) pendidik harus menjelaskan tujuan pembelajaran pada awal mengajar, karena dengan semakin jelas tujuan yang hendak dicapai maka akan makin besar pula motivasi peserta didik dalam belajar, (2) bagi peserta didik yang berprestasi, pendidik hendaklah memberikan hadiah. Pemberian hadiah secara efektif dan tepat guna akan memotivasi semangat peserta didik untuk belajar lebih giat, (3) pendidik berusaha menciptakan persaingan positif di antara peserta didiknya untuk meningkatkan prestasi belajarnya dan berusaha memperbaiki hasil prestasi yang telah dicapai sebelumnya.

\section{Counsellor}

Peran guru sebagai counsellor atau pembimbing adalah menjadi tempat bertanya bagi peserta didik yang mengalami kesulitan dalam belajar, memberi bantuan dengan menunjukkan jalan untuk memecahkan masalah, memperbaiki kesalahan yang telah dilakukan peserta didik, memberi dorongan dan memotivasi peserta didik untuk lebih giat dalam belajar. Konselor juga membantu dalam memperjelas masalah yang dialami peserta didik sebagaimana dikatakan Kennedy \& Charles (1990) most professional counselor or therapists, for example, try to make as clear as possible to clients the conditions under which they will be seen. Sebagai pembimbing atau konselor, guru dituntut untuk mempu mengidentifikasi peserta didik yang diduga mengalami kesulitan dalam belajar, melakukan diagnosis, prognosis, dan jika masih dalam batas kewenangannya harus membantu pemecahannya atau melakukan remedial. Oleh sebab itu seorang pendidik dituntut untuk memahami psikologi kepribadian dan ilmu kesehatan mental karena akan banyak membantu untuk menjalankan perannya sebagai konselor di samping sebagai guru yang mengampu mata pelajaran tertentu. 


\section{Evaluator}

Guru sebagai evaluator artinya dalam setiap pembelajaran guru haruslah melakukan evaluasi sesuai dengan indikator yang harus dicapai. Dalam mengevaluasi guru harus kreatif dengan berbagai cara dan memberikan penguatan agar keberhasilan belajar siswa dapat dirasakan. Kegiatan evaluasi ini haruslah dilakukan dengan cara yang adil dan objektif. Evaluasi yang adil tidak dipengaruhi oleh faktor keakraban, harus bersifat menyeluruh, memiliki kreteria yang jelas, dilakukan dalam kondisi yang tepat, dan dengan instrumen yang tepat pula sehingga mampu mengukur prestasi belajar peserta didik sebagaimana adanya. Selain beberapa peran guru tersebut di atas, dalam format pendidikan yang demokratis dan humanistik, pendidik juga harus berperan sebagai model idola atau figur teladan bagi anak didiknya. Seorang pendidik harus memiliki sifat-sifat yang positif seperti bertanggung jawab, disiplin, berwibawa, bijaksana, inovatif, kreatif, berdedikasi tinggi, berwawasan luas, mengayomi anak didik, tak kenal menyerah, lapang dada, sederhana, jujur, adil, lugas, empatik, serta berpenampilan menarik.

\section{Penutup}

Dalam konteks pendidikan yang demokratis dan humanistik, guru selain harus profesional dan memiliki kompetensi tertentu, ia juga harus mampu membantu anak didiknya untuk mengenali diri mereka sendiri sebagai manusia yang unik, membantu mereka dalam mengembangkan potensi-potensi yang ada secara optimal. Dalam hal ini pendidik tidak hanya menyampaikan materi pelajaran agar peserta didiknya dapat menguasai mata pelajaran kemudian memperoleh nilai yang baik atau lulus ujian. Sebab masih ada hal yang lebih penting yang harus menjadi perhatian seorang pendidik, yaitu proses pendewasaan dan membantu peserta didik untuk menemukan sebuah makna dari suatu materi pelajaran yang dapat diterapkan dalam kehidupan sehari-hari, memiliki kepribadian yang baik, santun dan berbudi yang merupakan inti dari tugas guru dalam mendidik. Dengan demikian dapat ditegaskan bahwa pendidik yang demokratis dan humanis adalah pendidik yang mampu membangun suasana belajar yang kundusif untuk belajar mandiri, bermakna, aktif, dinamis, dan menyenangkan.

\section{DAFTAR PUSTAKA}

Abd. Azis (2009). Filsafat Pendidikan: Sebuah Gagasan Membangun Pendidikan Islam. Yogyakarta: Teras

Abdul Mujib, et al (2006). Ilmu Pendidikan Islam. Jakarta : Kencana. 
Ahmad Tafsir (1994). Ilmu Pendidikan Dalam Perspektif Islam. Bandung: Remaja Rosdakarya.

Gerald Corey (1988) Teori dan Praktek Konseling dan Psikoterapi. Alih Bahasa Koeswara. Bandung: PT Eresco.

Hall, Calvin \& Linzey, Gardner (1985). Introduction to Theories of personality. New York: John Wiley \& sons, Inc.

Haryanto Al-Fandi (2011). Desain Pembelajaran yang Demokratis dan Humanis. Jogjakarta: Ar-Ruzz Media.

Kennedy, Eugene \& Charles, Sara C (1990). On Becoming a Counsellor. New York: Continuum Publising Company.

Miramba D. Ahmad (1987). Pengantar Filsafat Pendidikan Islam. Bandung: Al Ma'arif.

Mulyasa (2007). Menjadi Guru Profesional: Menciptakan Pembelajaran Kreatif dan Menyenangkan. Bandung: Rosdakarya.

Oemar Muhammad al Taomy al-Syahbani (1979). Filsafat Pendidikan Islam. Jakarta: Bulan Bintang.

Paul Suparman (2005). "Dampak RUU Guru Terhadap Kualitas dan Kesejahteraan Guru”. Kedaulatan Rakyat. Yogyakarta.

Syaiful Bahri Djamarah (2002). Psikologi Belajar. Jakarta: Rineka Cipta.

Zainal Aqib (2002). Profesionalisme Guru dalam Pembelajaran. Surabaya: Cendekia. 